\title{
Associative administration of cimetidine and exogenous melatonin on the endometrial receptors of estrogen, collagen and hormone levels in adult rats
}

\author{
Sandra Maria Souza da Silva ${ }^{1,2}$ (D), Laíse de Souza Elias ${ }^{1}$, Romildo Luciano da \\ Silva $^{3,4}$, Valéria Wanderley-Teixeira ${ }^{1}$ (D), Paloma Lys de Medeiros ${ }^{2,5,6}$, Jeymesson \\ Raphael Cardoso Vieira ${ }^{4}$ (D) \& Álvaro Aguiar Coelho Teixeira ${ }^{1,7}$ (D)
}

(1) Federal Rural University of Pernambuco, Department of Animal Morphology and Physiology, PostGraduate Program in Animal Bioscience, Avenue Dom Manoel de Medeiros, Dois Irmãos 52171-900, Recife, Pernambuco, Brazil. E-mail: valeria@dmfa.ufrpe.br

(2) Federal University of Pernambuco, Health Sciences Center, Post-Graduate Program in Therapeutic Innovation, Avenue Prof. Moraes Rego 1235, Cidade Universitária 50670-901, Recife, Pernambuco, Brazil. E-mail: sandrilineoz@gmail.com

(3) Federal University of Pernambuco, Health Sciences Center, Clinical Hospital, Department of Anatomy and Pathology, Avenue Professor Moraes Rego 1235, Cidade Universitária 50670-901, Recife, Pernambuco, Brazil. E-mail: romildo14luciano@gmail.com

(4) Federal University of Pernambuco, Biosciences Center, Department of Cytology, Histology and Embriology, Post-Graduate Program in Morphotechnology, Avenue Professor Moraes Rego 1235, Cidade Universitária 50670-901, Recife, Pernambuco, Brazil. E-mail: jeymesson@gmail.com

(5) Federal University of Pernambuco, Biological Sciences Center, Department of Histology and Embriology, Avenue Professor Moraes Rego 1235, Cidade Universitária 50670-901, Recife, Pernambuco, Brazil. E-mail: pmedlys@gmail.com

(6) Federal University of Pernambuco, Post-Graduate Program in Biotechnology, Northeast Biotechnology Network, Avenue Professor Moraes Rego 1235, Cidade Universitária 50670-901, Recife, Pernambuco, Brazil.

(7) Federal Rural University of Pernambuco, Department of Animal Morphology and Physiology, PostGraduate Program in Tropical Animal Science, Avenue Dom Manoel de Medeiros, Dois Irmãos 52171900, Recife, Pernambuco, Brazil. E-mail: alvaro.teixeira@ufrpe.br

Silva S.M.S., Elias L.S., Silva R.L., Wanderley-Teixeira V., Medeiros P.L., Vieira J.R.C. \& Teixeira Á.A.C. (2020) Associative administration of cimetidine and exogenous melatonin on the endometrial receptors of estrogen, collagen and hormone levels in adult rats. Pesquisa e Ensino em Ciências Exatas e da Natureza, 4: e1597. http://dx.doi.org/10.29215/pecen.v4i0.1597

Academic editor: Carina Scanoni Maia. Received: 25 October 2020. Accepted: 11 December 2020. Published: 20 December 2020.

Administração associativa de cimetidina e melatonina exógena nos receptores endometriais de níveis de estrogênio, colágeno e hormônio em ratos adultos

Resumo: Cloridrato de cimetidina, um bloqueador de receptores H2 das células parietais gástricas, que age reduzindo a secreção de ácido no estômago e tem sido estudado como substância xenoestrogênica. $\mathrm{O}$ uso crônico da cimetidina produz distúrbios homonais e toxidade no aparelho reprodutor masculino, além de reduzir o estradiol 2-hidroxilado e aumentar níveis séricos de estradiol e prolactina em mulheres, levando a hiperprolactinemia, que pode ser fator de risco para o câncer. A melatonina, neurohormônio sintetizado pela glândula pineal tem importante papel na função reprodutiva, regulando a produção de estrógeno, progesterrona e prolactina. $\mathrm{O}$ estudo testou a hipótese de que a melatonina pode bloquear ou reduzir os efeitos estrogênicos da cimetidina no estroma uterino, interferindo nos receptores de estrógeno, no teor de fibras colágenas e nos níveis hormonais em ratas adultas. Quarenta e cinco (45) ratas albinas divididas em três grupos: I - tratadas com placebo (controle); II - tratado com cimetidina (50 mg/kg) e III - tratado com 
cimetidina $(50 \mathrm{mg} / \mathrm{kg})$ associada à melatonina $(200 \mu \mathrm{g} / 100 \mathrm{~g})$. Os experimentos foram conduzidos por 7, 14 e 19 dias. Nos grupos tratados apenas com cimetidina, observou-se marcações mais intensas dos receptores $\mathrm{RE} \alpha$, maior distribuição das fibras colágenas no endométrio, elevação dos níveis séricos de estrogênio, prolactina e redução da progesterona, nos animais tratados por 19 dias. $\mathrm{Na}$ associação cimetidina e melatonina, acredita-se que a melatonina bloqueou esses efeitos. A melatonina tem atividade citoprotetora para efeitos crônicos da cimetidina no estroma endometrial, por reduzir ou prevenir o aumento da síntese de fibras de colágeno pelos fibroblastos regulando a atividade do estrogênio sérico, bem como a expressão de seus receptores endometriais, além de manter os níveis normais de progesterona e prolactina.

Palavras chave: Melatonina, receptor de estrógeno, xenoestrógeno, morfometria, níveis hormonais.

Abstract: Cimetidine hydrochloride, a blocker of $\mathrm{H} 2$ receptors in gastric parietal cells, acts by reducing the secretion of acid in the stomach and has been studied as a xenoestrogenic substance. The chronic use of cimetidine produces homonal disorders and toxicity in the male reproductive system, in addition to reducing 2-hydroxylated estradiol and increasing serum levels of estradiol and prolactin in women, leading to hyperprolactinemia, which can be a risk factor for cancer. Melatonin, a neurohormone synthesized by the pineal gland, it has an important role in reproductive function, regulating the production of estrogen, progesterone and prolactin. This study tested the hypothesis that melatonin can block or reduce the estrogenic effects of cimetidine in the uterine stroma interfering in the estrogen receptors, collagen fiber content and hormone levels in adult rats. Forty-five (45) albino female rats were divided into three groups: I - treated with placebo (control); II - treated with cimetidine $(50 \mathrm{mg} / \mathrm{kg}$ ) and III - treated with cimetidine $(50 \mathrm{mg} / \mathrm{kg})$ associated with melatonin $(200 \mu \mathrm{g} / 100 \mathrm{~g})$. Experiments were conducted for 7,14 and 19 days. Cimetidine promoted more intense marks of RE $\alpha$ receptors in the uterus of animals treated for 19 days, in the distribution of collagen fibers in the endometrium, elevated serum levels of estrogen and prolactin and progesterone reduction. Melatonin associated with cimetidine has blocked these effects. The melatonin has cytoprotective activity to cimetidine chronic effects on endometrial stroma by reducing or preventing the increase in the synthesis of collagen fibers by fibroblasts by regulating the activity of serum estrogen as well as the expression of its endometrial receptors, besides maintaining the normal levels of progesterone and prolactin.

Key words: Melatonin, estrogen receptor, xenoestrogen, uterus, morphometry, hormone levels.

\section{Introduction}

Cimetidine is an $\mathrm{H}_{2}$-blocker drug from gastric parietal cells used to treat dyspepsia, gastric and duodenal ulcers, which not only inhibits the stimulating effects of histamine on gastric acid secretion, but also the actions of all other gastric stimulants (Saiyn 2012; Cotton et al. 2013). Experimental studies have demonstrated affinity of cimetidine by RE $\alpha$ and RE $\beta$ estrogen receptors, acting similar to them, thus exerting xenoestrogen action (Takeshi et al. 2002; Sinha et al. 2006). These two receptor subtypes have different expression patterns in the various organs (Kuiper et al. 1996, 1997; Zuloaga et al. 2013), the RE $\alpha$ with greater expression in uterus and testis, and ER $\beta$ in prostate and ovary (Mosselman et al. 1996).

The literature reports that chronic use of cimetidine in men may be associated with side effects such as, hyperestrogenism resulting in hyperprolactinemia and gynecomastia (Nahas et al. 2006). Cimetidine has also been reported as toxic to reproduction in male rats, which present morphological changes in the reproductive tract, characterized by changes in peritubular myoid cells and significant reduction in the weight of accessory sex organs (França et al. 2000; SassoCerri \& Cerri 2008; Koshimizu et al. 2013). It was also demonstrated that cimetidine increases serum levels of estrogen and prolactin (PRL) in women (Michnovicz \& Galbraith 1991), leading to hyperprolactinemia, which can be a risk factor for breast cancer in postmenopausal women (Hankinson et al. 1999).

The neurohormone melatonin synthesized by the pineal gland, which is secreted rhythmically, has demonstrated key role in the reproductive function in both seasonal and nonseasonal animals characterized by regulating the production of estrogen and progesterone, uterine contractility inhibition, regulation of growth and ovarian activity (Maekawa et al. 2007; Zarazaga et al. 2011). 
According to Freeman et al. (2000), melatonin-treated animals showed decrease in the number of lactotrophs, estradiol reduction and consequent decreased secretion of PRL, once estrogen is a hormone that stimulates the PRL production by regulating the gene expression for PRL and its sensitivity associated with melatonin levels (Close \& Freeman 1997). Furthermore, melatonin influences on the functioning of the genital system, especially in the uterus and gonads (Teixeira et al. 2004; Adriaens et al. 2006; Maganhin et al. 2008; Zarazaga et al. 2012).

Knowing that estrogen mediates pro-reproductive effects through actions in several organs of the female reproductive system (ovaries, fallopian tubes, uterus and placenta formation) and biochemical processes (Rosselli et al. 2000; Deroo \& Korach 2006; Zoloaga et al. 2013), experimental studies of reproduction regarding the adverse effects caused by frequent exposure to xenoestrogen substances have been performed, reaffirming the importance and constant level of exposure at which the current world population is exposed to (Bromer et al. 2010; Zhong et al. 2013). Thus, the present study tested the hypothesis that melatonin can block or reduce the estrogenic effects of cimetidine in uterine stroma, interfering with ER $\alpha$-receptor expression, content of collagen fibers and hormone levels (estrogen, progesterone and prolactin) in adult rats.

\section{Materials and Methods}

\section{Ethics statement}

This study was carried out in strict accordance with the recommendations in the Guide for the Care and Use of Laboratory Animals of the National Institutes of Health. The protocol was approved by the Committee on the Ethics of Animal Experiments of the Federal Rural University of Pernambuco (Permit Number: $n^{\circ}$ 018/2013).

\section{Experimental animals}

A total of 45 albino rats (Rattus norvegicus albinus) with 90 days of age coming from the Department for Morphology and Physiology Animal, Federal Rural University of Pernambuco (UFRPE). The females were kept in cages with food and water ad libitum, temperature of $22^{\circ} \mathrm{C}$ and artificial lighting that sets a photoperiod of 12 hours light and 12 hours dark. The females were divided into three groups of 15 animals each, and the treatment performed for 7, 14 and 19 days. Group I - rats treated with placebo (control), Group II - Rats treated with cimetidine, Group III - rats treated with cimetidine associated with melatonin. Five animals per evaluation period were used in the analyses.

\section{Cimetidine administration}

It was administered at a dose of $50 \mathrm{mg} / \mathrm{kg}$ i.p. cimetidine (Tagamet ${ }^{\circ}$, SmithKline Beecham, Brazil) (Sasso-Cerri \& Cerri 2008). The set of dosage selected followed the protocol of measures employed in humans, ranging from $400 \mathrm{mg} / \mathrm{kg} /$ day for the treatment of hyperacidity to 800 $\mathrm{mg} / \mathrm{kg} / \mathrm{day}$ for the treatment of acute ulcers. In rats, these doses are equivalent to $35 \mathrm{mg} / \mathrm{kg} / \mathrm{day}$ and $70 \mathrm{mg} / \mathrm{kg} /$ day, respectively. Thus, an intermediate dose $(50 \mathrm{mg} / \mathrm{kg} /$ day $)$ was chosen following the methodology proposed by França et al. (2000).

\section{Melatonin administration}

Melatonin (Sigma, St. Louis, MO, USA) was administered at a dose of $200 \mu \mathrm{g} / 100 \mathrm{~g}$ animal body weight by subcutaneous injections in the early evening (18:00), dissolved in ethanol (0.02 $\mathrm{mL}$ ) and diluted in $1 \mathrm{~mL}$ of $0.9 \%$ saline solution (Dair et al. 2008). The control group I received ethanol in saline solution at the same concentration.

\section{Hormone dosages}


Blood samples were collected on days 7, 14 and 19 days via tail vein puncture (Fluttert et al. 2000) for assessment of serum levels of estrogen, progesterone and prolactin. They were centrifuged at a temperature of $4^{\circ} \mathrm{C}$ with the speed of $3000 \mathrm{rpm}$ for 10 minutes, and supernatant frozen at $-20^{\circ} \mathrm{C}$ until the hormonal dosages were performed by the Enzyme Linked Immunosorbent Assay (ELISA) using commercial kits (Teixeira et al. 2004). The samples were analyzed in triplicate.

\section{Immunohistochemical study}

The females were anesthetized in their evaluation periods with ketamine hydrochloride $(80 \mathrm{mg} / \mathrm{kg})$ and xylazine $(6 \mathrm{mg} / \mathrm{kg}$ ) intramuscularly. Fragments of the uterus were fixed in $10 \%$ buffered formalin and processed for paraffin embedding. The sections were subjected to antigen retrieval in $10 \mathrm{mM}$ sodium citrate solution, $\mathrm{pH}$ 6.0, in a moist chamber for 15 minutes at $98^{\circ} \mathrm{C}$. Subsequently, it was performed the blocking of endogenous peroxidase (Peroxidase-Blocking Reagent-SM802) for 5 minutes, and incubation in humid chamber with primary antibody mouse monoclonal Anti-Human estrogen receptor $\alpha$ clone 1D5 (Dakocytomation - CA USA) undiluted for $1 \mathrm{~h}$ at room temperature. This was followed by incubation with secondary antibody linked to peroxidase (HRP Envision Flex ${ }^{\circledR}$ - Dakocytomation - CA, USA. SM805 Code) for 20 minutes, washed in Tris buffer and revealed by DAB (3.3'-diaminobenzidine - Dakocytomation - CA USA. SM803), for ten minutes in the dark. Slides were counterstained with hematoxylin.

\section{Histomorphometric study}

Cuts from the uterus stained with Masson's trichrome were used for collagen analysis. Images of four fields per blade of each animal were captured and transferred to the histomorphometric program ImageJ (version 1.41 NIH, Bethesda, USA), regularly calibrated to measure the desired areas in micrometer by defining the contours of the regions stained, with the aid of the mouse, thereby assessing the process of deposition of collagen fibers (Figure 1AB).
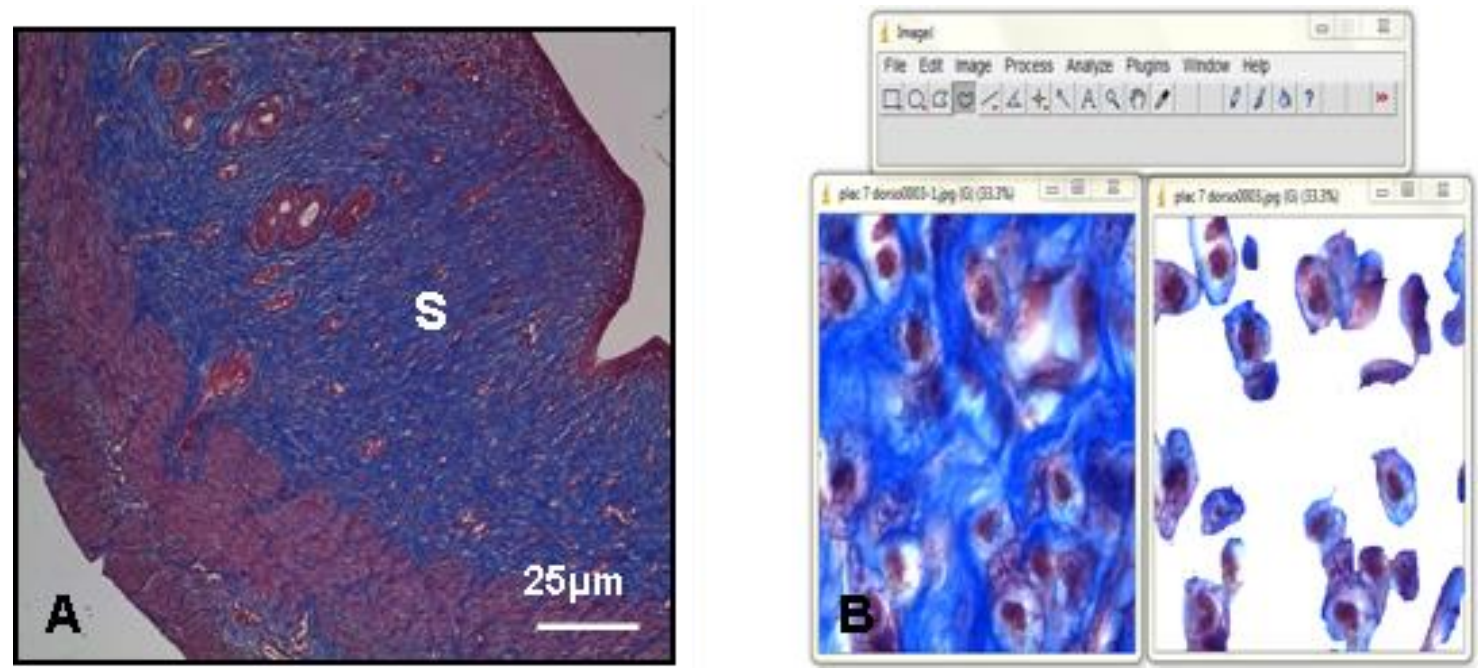

Figure 1. Cuts from the uterus stained with Masson's trichrome for collagen analysis: A. Cross section of rat uterus in the placebo group. Region uterine stroma (S), used for measurement of collagen fibers. Masson Trichrome staining; B. Measurement of area of collagen fibers using ImageJ software, with selection tool for the study area.

\section{Statistical analysis}

Statistical analysis of serum levels of estrogen, progesterone and prolactin, and quantification of collagen fibers was performed using the nonparametric method of KruskalWallis test, with Dunn's post-hoc $(\mathrm{p}<0.05)$. 


\section{Cimetidine and exogenous melatonin on endometrial receptors}

\section{Results}

\section{Immunohistochemical analysis}

The immunohistochemical observations of $\mathrm{RE} \alpha$ revealed different marking intensities and concentration in cells throughout the period of administration of substances in the experimental groups except the control, which maintained a regular nuclear staining during the periods of 7, 14 and 19 days (Figures 2A-B, 3A-B, 4A-B). When comparing the nuclear markings in the groups cimetidine and cimetidine associated with melatonin at 7,14 and 19 days these samples showed significant difference in marking, so that in the uterus of those that received cimetidine associated with melatonin there was higher concentration of marked cells in the period of 19 days, but with lower intensity (Figure 4E-F) when compared to the uterus of rats given cimetidine (Figure 4C-D).
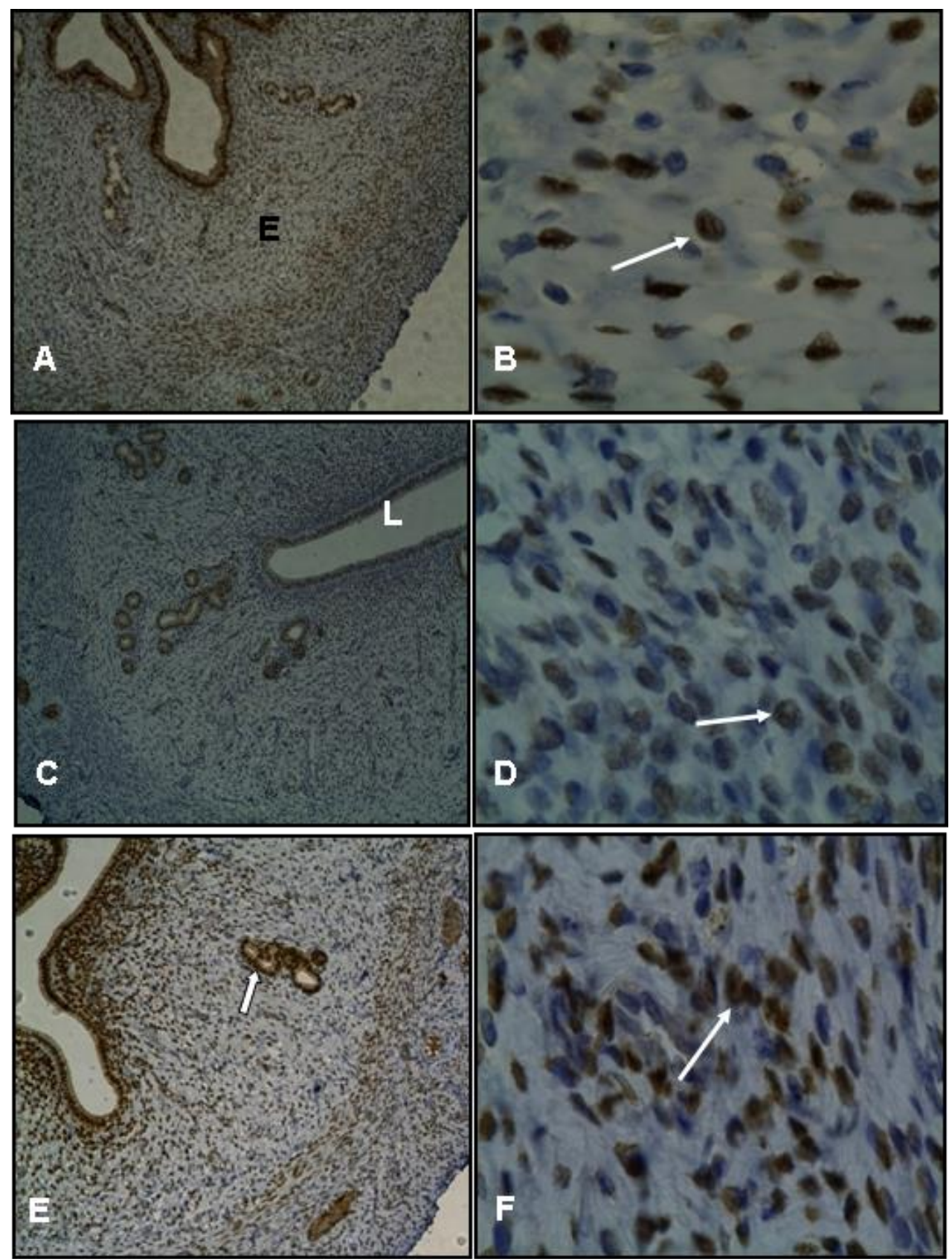

Figure 2. Immunohistochemistry of $\alpha$-estrogen receptors in the endometrium of rats treated with placebo (A-B), cimetidine (C-D) and cimetidine associated with melatonin (E-F) for 7 days. Uterine stroma (S); endometrial glands (arrow); long arrow - positively marked nuclei; uterine lumen (L). Against stained with hematoxylin Harris. 


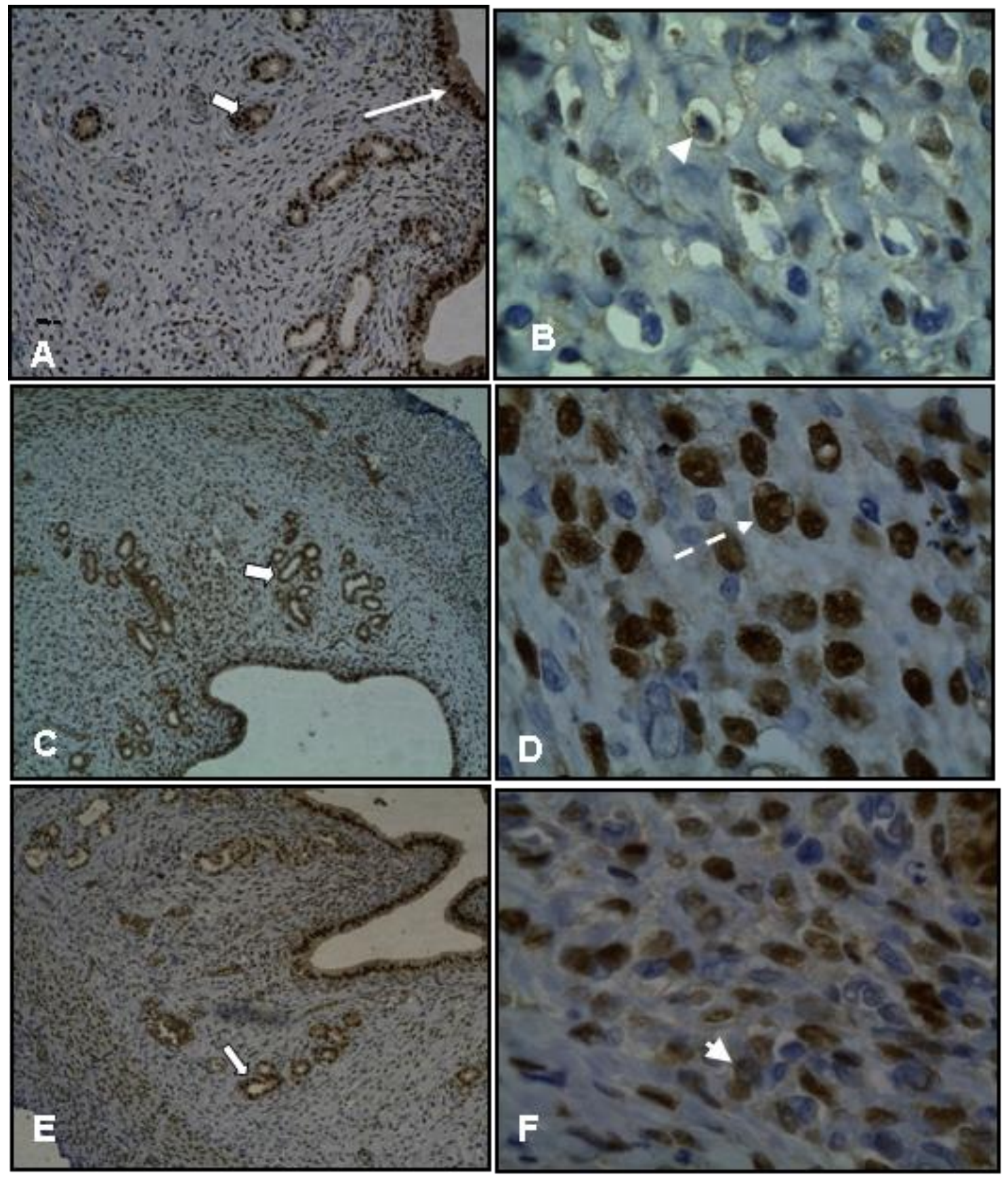

Figure 3. Immunohistochemistry of endometrial $\alpha$ - estrogen receptors of rats treated with placebo (A-B), cimetidine (C-D) and cimetidine associated with melatonin (E-F) for 14 days. Endometrial glands positively stained (short arrow); epithelial marking of receptors (long arrow), strongly positive nuclei (dashed arrow), nuclei marked with lower intensity (arrowhead). Against stained with hematoxylin Harris.

\section{Histomorphometric study of collagen fibers}

Histomorphometric analysis of the distribution of collagen fibers in the endometrium revealed a higher concentration of these fibers in the stroma of rats treated with cimetidine (Figure 5B, E and $\mathrm{H}$ ) compared to endometrial stroma of rats treated with placebo and the combination of cimetidine and melatonin (Figure 5A, C-D, F-G and I). However, the statistical analysis revealed increased amount of collagen fibers in the endometrial stroma of rats treated with cimetidine in periods of 14 and 19 days (Figures 6-8). 

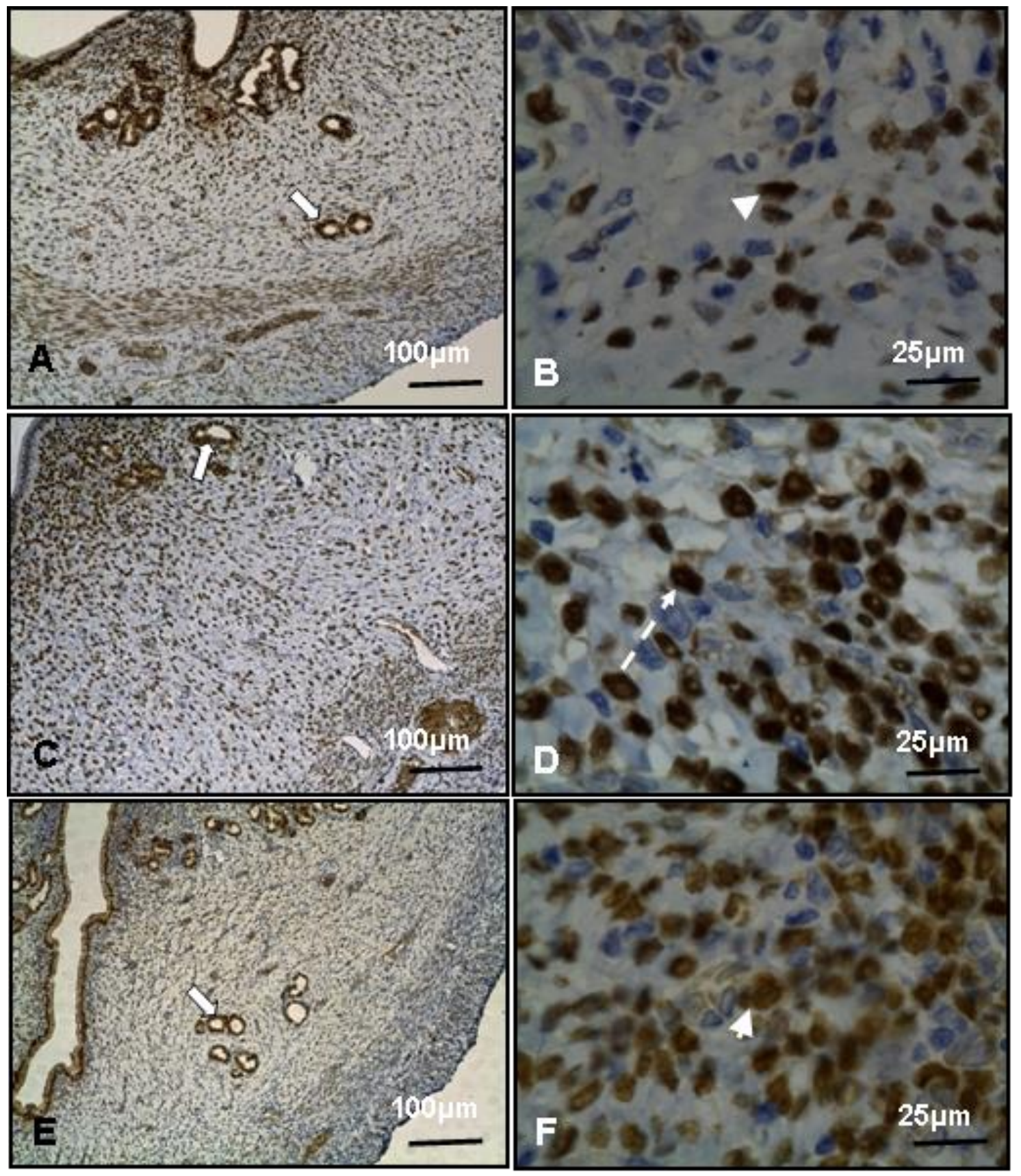

Figure 4. Immunohistochemistry of endometrial $\alpha$-estrogen receptors of rats treated with placebo (A-B), cimetidine (G-D) and cimetidine associated with melatonin (E-F) for 19 days. Endometrial glands positively stained (short arrow); epithelial marking of receptors (long arrow), nuclei strongly positive (dashed arrow), nuclei marked with lower intensity (arrowhead). Against stained with hematoxylin Harris.

\section{Serum levels of estradiol, progesterone and prolactin}

Dosages of serum levels of estrogen and prolactin revealed a significant increase of these hormones in the rats only during the 19 days of cimetidine administration. The progesterone during the same period and experimental group showed significant reduction. The combined treatment maintained serum levels of these hormones similar to those shown by rats treated with placebo at all time points evaluated (Tables 1-3). 

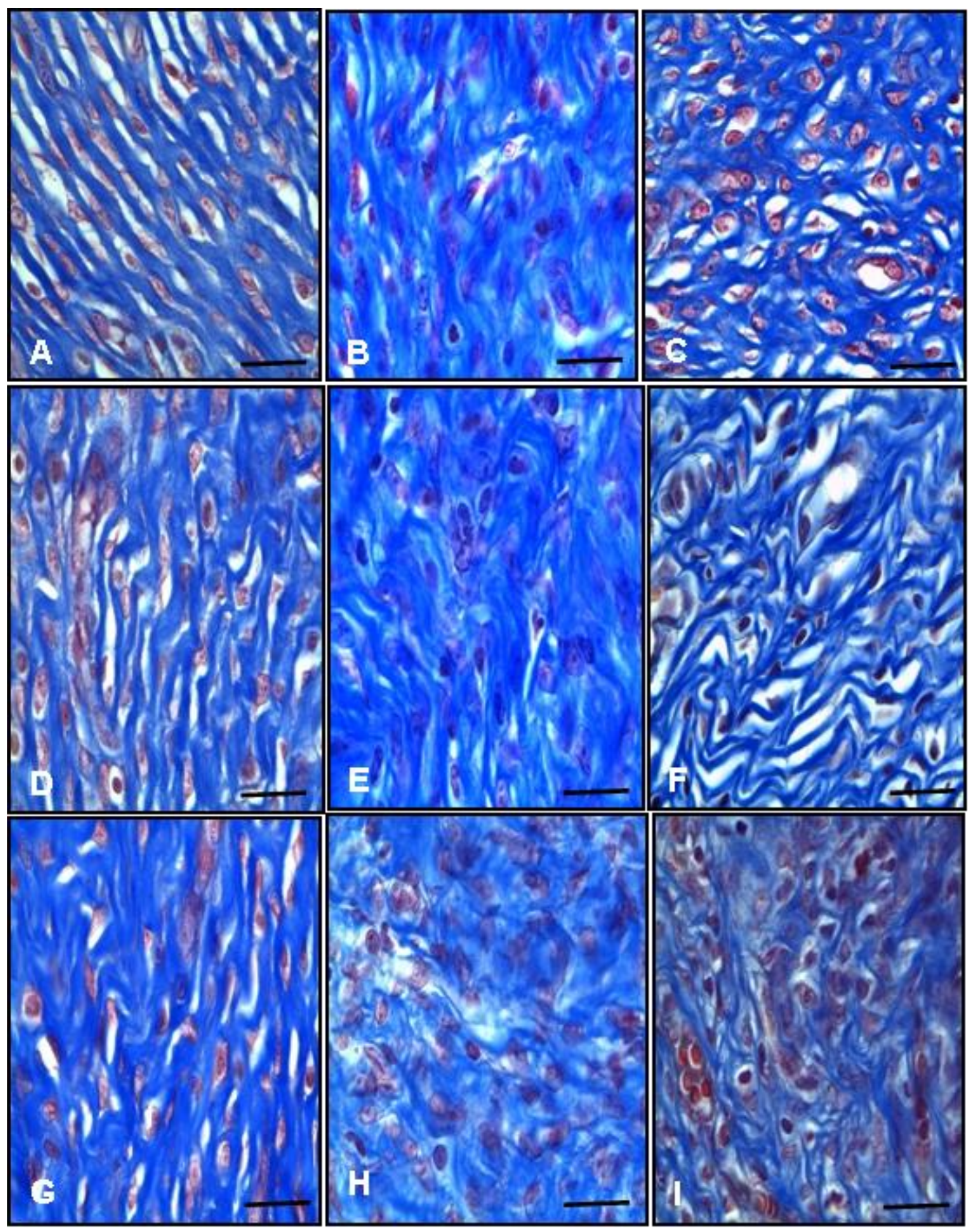

Figure 5. Uterine stromal histochemistry of experimental groups of female rats. Control (A, D and G - 7, 14 and 19 days, respectively), cimetidine (B, E and $\mathrm{H}-$ 7, 14 and 19 days, respectively) and cimetidine associated with melatonin (C, F and I - 7, 14 and 19 days, respectively). Masson trichrome. Scale bar: $25 \mu \mathrm{m}$.

Table 1. Means of serum levels of estrogen $(\mathrm{ng} / \mathrm{mL})$ in female rats of the experimental groups. Means followed by different letters differ significantly by Kruskal-Wallis test $(p<0.05)$.

\begin{tabular}{|c|c|c|c|c|}
\hline Groups & I & II & III & $\mathbf{P}$ \\
\hline \multicolumn{5}{|c|}{ Estrogen } \\
\hline 7 Days & $414.66 \pm 5.23 a$ & $407.88 \pm 4.03 a$ & $410.34 \pm 5.76 a$ & 0.0809 \\
\hline 14 Days & $489.19 \pm 7.55 a$ & $502.77 \pm 6.21 \mathrm{a}$ & $499.36 \pm 5.93 a$ & 0.1055 \\
\hline 19 Days & $482.79 \pm 3.50 \mathrm{a}$ & $519.66 \pm 4.19 b$ & $477.83 \pm 6.29 a$ & 0.0304 \\
\hline
\end{tabular}


Table 2. Means of serum levels of progesterone $(\mathrm{ng} / \mathrm{mL})$ in female rats of the experimental groups. Means followed by different letters differ significantly by Kruskal-Wallis test $(\mathrm{p}<0.05)$.

\begin{tabular}{ccccc}
\hline Groups & I & II & III & P \\
\hline & & Progesterone & & \\
\hline 7 Days & $536.06 \pm 6.82 \mathrm{a}$ & $546.97 \pm 9.20 \mathrm{a}$ & $534.93 \pm 9.53 \mathrm{a}$ & 0.1472 \\
14 Days & $550.20 \pm 5.17 \mathrm{a}$ & $545.99 \pm 2.75 \mathrm{a}$ & $547.39 \pm 3.02 \mathrm{a}$ & 0.1024 \\
19 Days & $563.37 \pm 3.48 \mathrm{a}$ & $515.38 \pm 1.60 \mathrm{~b}$ & $564.36 \pm 4.76 \mathrm{a}$ & 0.0145 \\
\hline
\end{tabular}

Table 3. Means of serum levels of prolactin $(\mathrm{ng} / \mathrm{mL})$ in female rats of the experimental groups. Means followed by different letters differ significantly by Kruskal-Wallis test $(\mathrm{p}<0.05)$.

\begin{tabular}{ccccc}
\hline Groups & I & II & III & P \\
\hline & & Prolactin & & \\
\hline 7 Days & $2.07 \pm 0.43 \mathrm{a}$ & $2.13 \pm 0.58 \mathrm{a}$ & $2.08 \pm 0.47 \mathrm{a}$ & 0.9828 \\
14 Days & $2.09 \pm 0.30 \mathrm{a}$ & $2.23 \pm 0.36 \mathrm{a}$ & $2.04 \pm 0.49 \mathrm{a}$ & 0.7518 \\
19 Days & $2.24 \pm 0.54 \mathrm{a}$ & $6.03 \pm 0.71 \mathrm{~b}$ & $1.98 \pm 0.43 \mathrm{a}$ & 0.0021 \\
\hline
\end{tabular}

\section{Discussion}

The results of immunohistochemistry showed differentiation in intensity and positivity markup for estrogen receptors in endometrial stroma in rats of experimental groups, being more expressive in nuclear receptors in rats that received cimetidine associated with melatonin in the last assessment period. However, although RE $\alpha$ receptors have presented with greater expression in endometrium of this group of rats, these showed a lower intensity.

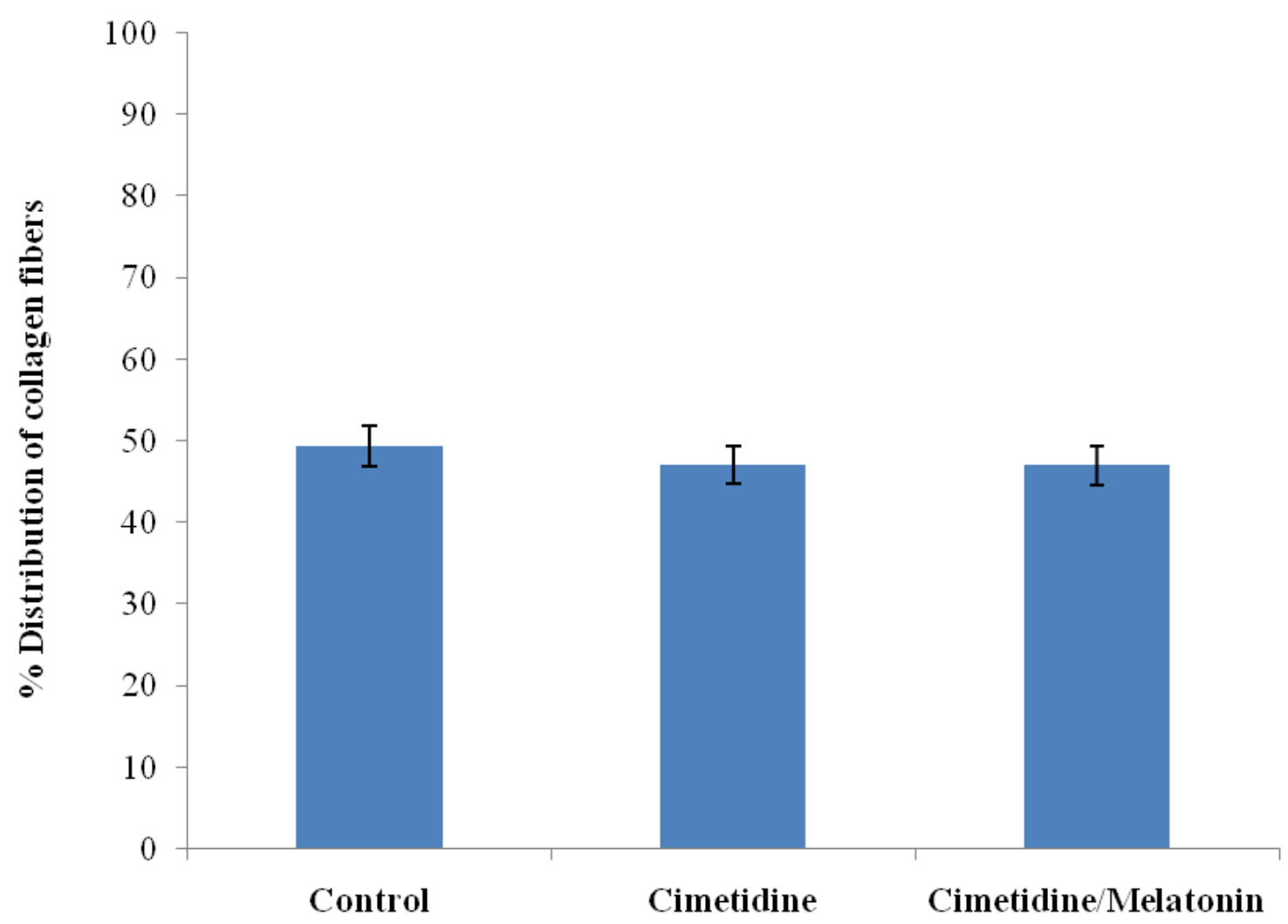

Figure 6. Distribution of collagen fibers in the uterus of adult female rats treated with placebo, cimetidine and cimetidine associated with melatonin for 7 days (Kruskal-Wallis test, $\mathrm{p}=0.6808$ ). 


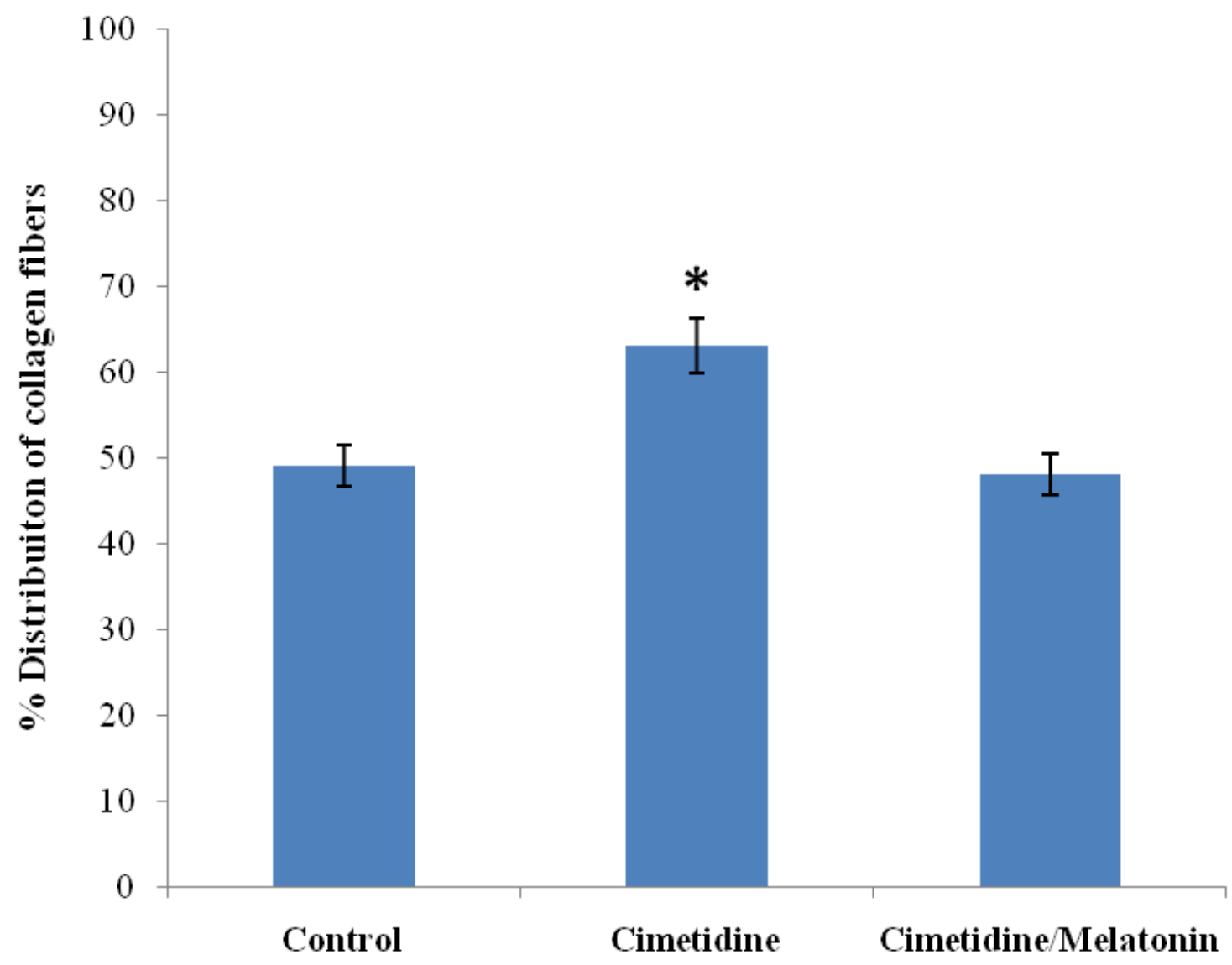

Figure 7. Distribution of collagen fibers in uterus of adult female rats treated with placebo, cimetidine and cimetidine associated with melatonin for 14 days (Kruskal-Wallis test, $\mathrm{p}=0.0105$ ).

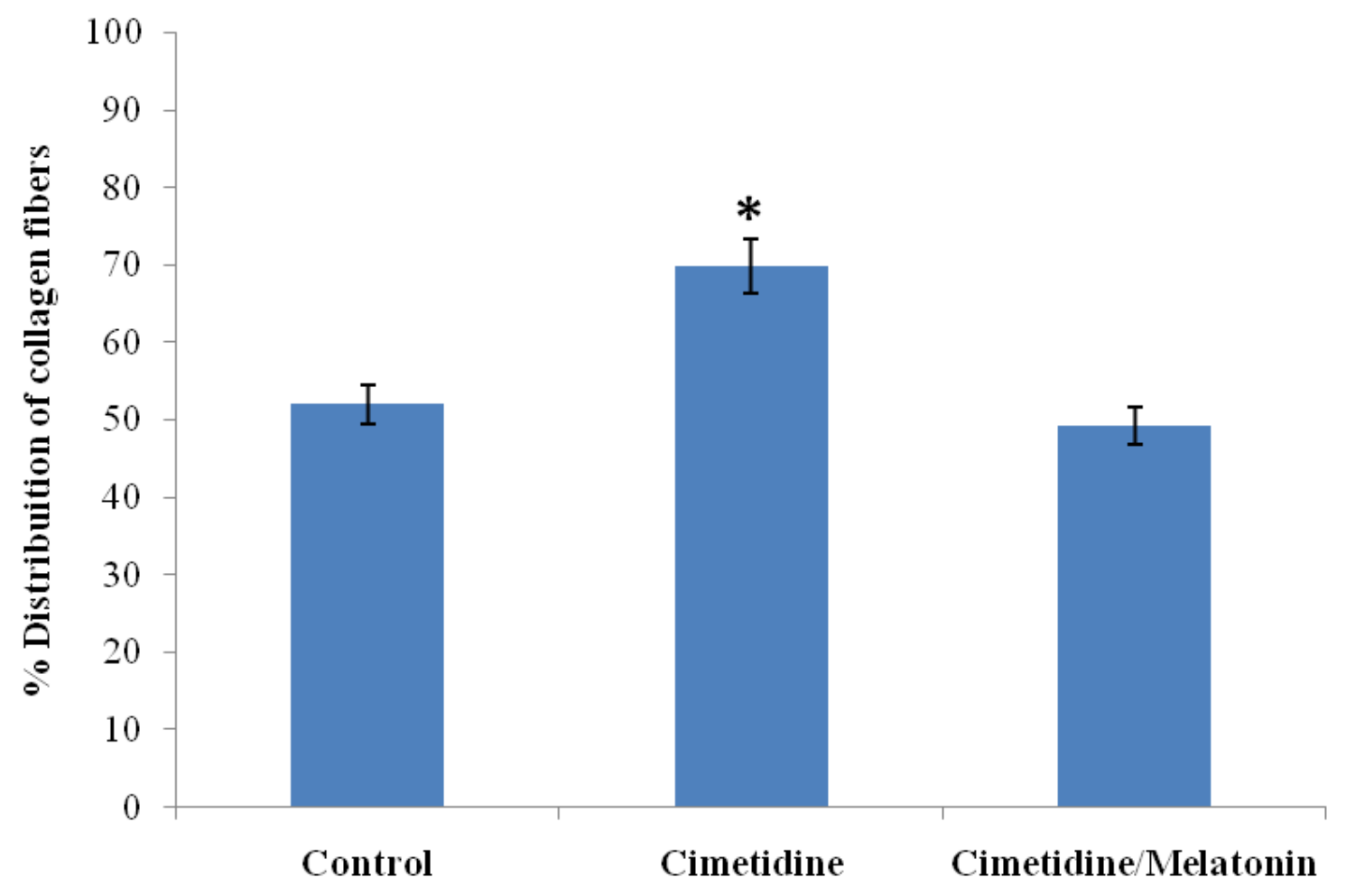

Figure 8. Distribution of collagen fibers in the uterus of adult female rats treated with placebo, cimetidine and cimetidine associated with melatonin for 19 days (Kruskal-Wallis test, $\mathrm{p}=0.0052$ ). 
Biomarkers are commonly used as indicators of biochemical, physiological and histological exposure to xenobiotics or effect of chemical contaminants (Jesus \& Carvalho 2008). Thus, the presence and intensity of the marking in the receptors reflecta the cell positiveness and the concentration thereof (Robinson et al. 2010; Koshimizu et al. 2013). According to Martin et al. (2008), the increase or decrease in the concentration of endometrial estrogen receptors (ER) and progesterone (PR) is associated with the expression of mRNA for these receptors, suggesting the existence of mechanisms of regulation of endometrial ER and PR involving the own hormones, once the concentration of such receptors occur simultaneously with the elevation of plasmatic concentration and tissue hormones. Thus, the lower staining intensity observed in the group receiving cimetidine associated with melatonin may be due to the antiestrogenic action of melatonin (Freeman et al. 2000; Karadayian et al. 2012), a fact further confirmed by the increased serum dosage of $17 \beta$-estradiol obtained in the experimental groups when treated exclusively with cimetidine. Thus, data like this confirm the ability of estrogen activation of cimetidine, which acts by altering the pattern of synthesis and hormonal secretion of estrogen (17 $\beta$-estradiol), and thus regulating the sexual behavior and reproductive function (Akingbemi et al. 2004; Bredfeldt et al. 2010).

The analysis of results for plasmatic concentrations of progesterone show that melatonin blocked the cimetidine effect by maintaining the hormone at levels similar to those of control animals, which corroborates studies by Taketani et al. (2011), Xiang et al. (2012) and Uygur et al. (2013) who reported that melatonin protects the luteal cells of the granular layer, increasing progesterone production in the follicle during ovulation and thus improving the fertilization rate. Furthermore, the increased plasmatic dosage of prolactin in cimetidine-treated group confirms the stimulator role of estrogen (also elevated in animals from this group) on prolactin secretion, which according to Katayama \& Fishman (1982), Christin-Maitre et al. (2007) and Surazynski et al. (2013), induces hyperprolactinemia in male Wistar rats when treated by continuous administration of estrogen.

It is known that the endometrium's fibrillar structure is controlled by sexual hormones (Oxlund et al. 2010). The estrogen acts by stimulating the synthesis of mRNA for collagen fibers (sindecan-3), modeling the distribution pattern of these fibers (Myllyharrju \& Kivirikko 2004; Silva et al. 2011). Thus, the present study demonstrated the xenoestrogen action of cimetidine by stimulating the synthesis of collagen fibers in the endometrial stroma in periods of 14 and 19 days, while the association with melatonin inhibited this effect. It is known that fibroblasts are estrogen-dependent and melatonin can be a regulating factor in the synthesis of collagen fibers synthesized by the fibroblasts, once pinealectomized rats exhibit high concentration of collagen fibers in the endometrium (Teixeira et al. 2002; Medeiros et al. 2003). Thus, it is concluded that melatonin has cytoprotective activity to the cimetidine effects on endometrial stroma by reducing or preventing the increase in the synthesis of collagen fibers by fibroblasts by regulating the activity of serum estrogen as well as the expression of its endometrial receptors, besides maintaining the normal levels of progesterone and prolactin.

\section{Acknowledgements}

At the sector of pathology Hospital of Clinics, Federal University of Pernambuco, for performing the immunoblots and reviewers of this work.

\section{References}

Adriaens I., Jacquet P., Cortvrindt R., Janssen K. \& Smitz J. (2006) Melatonin has dose-dependent effects on folliculogenesis, oocyte maturation capacity and steroidogenesis. Toxicology, 228: 333-343. I: http://dx.doi.org/10.1016/j.tox.2006.09.018

Akingbemi B.T., Sottas C.M., Koulova A.I., Klinefelter G.R. \& Hardy M.P. (2004) The inhibition of testicular steroidogenesis by the xenoestrogen bisphenol $\mathrm{A}$ is associated with reduced 
pituitary luteinizing hormone secretion and decreased steroidogenic enzyme gene expression in rat Leydig cells. Endocrinology, 145(2): 592-603. http://dx.doi.org/10.1210/en.2003-1174

Bredfeldt T.G., Greathouse K.L., Safe S.H., Hung M.C., Bedford M.T. \& Walker C.L. (2010) Xenoestrogen-induced regulation of EZH2 and histone methylation via estrogen receptor signaling to PI3K/AKT. Molecular Endocrinology, 24(5): 993-1006.

https://doi.org/10.1210/me.2009-0438

Bromer J.G., Zhou Y., Taylor M.B., Doherty L. \& Taylor H.S. (2010) Bisphenol-A exposure in utero leads to epigenetic alterations in the developmental programming of uterine estrogen response. Federation of American Societies for Experimental Biology, 24: 2273-2280. https://doi.org/10.1096/fj.09-140533

Christin-Maître S., Delemer B., Touraine P. \& Young J. (2007) Prolactinoma and estrogens: pregnancy, contraception and hormonal replacement therapy. Annales d'Endocrinologie, 68: 106-112. https://doi.org/10.1016/j.ando.2007.03.008

Close F.T. \& Freeman M.E. (1997) Effects of ovarian steroid hormones on dopamine-controlled prolactin secretory responses in vitro. Neuroendocrinology, 65: 430-435. https://doi.org/10.1159/000127206

Cotton R.B., Shah L.P., Stanley D.P., Ehinger N.J., Brown N., Shelton E.L., Slaughter J.C., Baldwin H.S., Paria B.C. \& Reese J. (2013) Cimetidine-associated patent ductus arteriosus is mediated via a cytochrome $\mathrm{P} 450$ mechanism independent of $\mathrm{H} 2$ receptor antagonism. Journal of Molecular and Cellular Cardiology, 59: 86-94. https://doi.org/10.1016/j.yjmcc.2013.02.010

Dair E.L., Simões R.S., Simões M.J., Romeu L.R.G., Oliveira-Filho R.M. \& Haidar M.A. (2008) Effects of melatonin on the endometrial morphology and embryo implantation in rats. Fertility and Sterility, 89(5): 1299-1305. https://doi.org/10.1016/j.fertnstert.2007.03.050

Deroo B.J. \& Korach K.S. (2006) Estrogen receptors and human disease. The Journal of Clinical Investigation, 116(3): 561-570. https://doi.org/10.1172/JCI27987

Fluttert M., Dalm S. \& Oitzl M.S. (2000) A refined method for sequencial blood sampling by tail incision in rats. Laboratory Animals, 34(4): 372-378. https://doi.org/10.1258/002367700780387714

França L.R., Leal M.C., Sasso-Cerri E., Vasconcelos A., Debeljuk L. \& Russell L.D. (2000) Cimetidine (Tagamet ${ }^{\circ}$ ) is a reproductive toxicant in male rats affecting peritubular cells. Biology of Reproduction, 63: 1403-1412. https://doi.org/10.1095/biolreprod63.5.1403

Freeman M.E., Kanyicska B., Lerant A. \& Nagy G. (2000) Prolactin: structure, function, and regulation of secretion. Physiological Reviews, 80(4): 1523-1631.

https://doi.org/10.1152/physrev.2000.80.4.1523

Hankinson S.E., Willett W.C., Michaud D.S., Manson J.E., Colditz G.A. \& Longcope C. (1999) Plasma prolactin levels and subsequent risk of breast cancer in postmenopausal women. Journal of the National Cancer Institute, 91(7): 629-634. https://doi.org/10.1093/jnci/91.7.629

Jesus T.B. \& Carvalho C.E.V. (2008) Using biomarkers in fish to detect environmental contamination by mercury. Oecologia Australis, 12: 680-693.

Karadayian A.G., Mac Laughlin M.A. \& Cutera R.A. (2012) Estrogen blocks the protective action of melatonin in a behavioral model of ethanol-induced hangover in mice. Physiology \& Behavior, 107(2): 181-186. https://doi.org/10.1016/j.physbeh.2012.07.003

Katayama S. \& Fishman J. (1982) 2-Hydroxyestrone suppresses and 2-methoxyestrone augments the preovulatory prolactin surge in the cycling rat. Endocrinology, 110(4): 1448-1450. https://doi.org/10.1210/endo-110-4-1448

Koshimizu J.Y., Beltrame F.L., Pizzol J.P., Paulo S.C., Caneguim B.H. \& Sasso-Cerri E. (2013) NF$\mathrm{kB}$ overexpression and decreased immunoexpression of $\mathrm{AR}$ in the muscular layer is related to structural damages and apoptosis in cimetidine-treated rat vas deferens. Reproductive Biology and Endocrinology, 11: 29. http://dx.doi.org/10.1186/1477-7827-11-29

Kuiper G.G., Enmark E., Pelto-Huikko M., Nilsson S. \& Gustafsson J.A. (1996) Cloning of a novel estrogen receptor expressed in rat prostate and ovary. Proceedings of the National Academy of Sciences, 93(12): 5925-5930. http://dx.doi.org/10.1073/pnas.93.12.5925 
Kuiper G.G., Carlsson B., Grandien K., Enmark E., Haggblad J., Nilsson S. \& Gustafsson J.A. (1997) Comparison of the ligand binding specificity and transcript tissue distribution of estrogen receptors $\alpha$ and $\beta$. Endocrinology, 138(3): 863-870. http://dx.doi.org/10.1210/endo.138.3.4979

Maekawa R., Tamura H., Taniguchi K., Taketani T. \& Sugino A. (2007) Role and regulation of maternal melatonin during pregnancy in rats. Biology of Reproduction, 77: 105-110. https://doi.org/10.1093/biolreprod/77.s1.105b

Maganhin C.C., Ferraz A.A.C., Halley J.H., Fuchs L.F.P., Oliveira-Júnior I.S. \& Simões M.J. (2008) Efeitos da melatonina no sistema genital feminino: breve revisão. Revista da Associação Medica Brasileira, 54(3): 267-271. https://doi.org/10.1590/S0104-42302008000300022

Martin I., Torres Neto R., Oba E., Buratini J.Jr., Binelli M. \& Laufer-Amorim R. (2008) Immunohistochemical detection of receptors for oestrogen and progesterone in endometrial glands and stroma during the oestrous cycle in Nelore (Bos taurus indicus) cows. Reproduction in Domestic Animal, 43(4): 415-421. https://doi.org/10.1111/j.1439-0531.2007.00928.x

Medeiros J.P., Wanderley-Teixeira V., Teixeira A.A.C., Baratella-Evencio L. \& Evencio Neto J. (2003) Ultrastructural analysis of pinealectomy and lack of light influence over collagen in the endometrium of rats. International Journal of Morphology, 21(3): 231-235. http://dx.doi.org/10.4067/S0717-95022003000300008

Michnovicz J.J. \& Galbraith R.A. (1991) Cimetidine inhibits catechol estrogen metabolism in women. Metabolism Clinical and Experimental, 40(2): 170-174. https://doi.org/10.1016/0026-0495(91)90169-W

Mosselman S., Polman J. \& Dijkema R. (1996) ERb: identification and characterization of a novel human estrogen receptor. FEBS Letters, 392: 49-53. http://dx.doi.org/10.1016/0014-5793(96)00782-x

Myllyharrju J. \& Kivirikko K.L. (2004) Collagens, modifying enzymes and their mutations in humans, flies and worms. Trens in Genetics, 20: 33-43. http://dx.doi.org/10.1016/j.tig.2003.11.004

Nahas E.A.P., Nahás-Neto J., Pontes A., Dias R. \& Fernandes C.E. (2006) Estados hiperprolactinêmicos - inter-relações com o psiquismo. Revista de Psiquiatria Clínica, 33: 6873. http://dx.doi.org/10.1590/S0101-60832006000200006

Oxlund B.S., Ortoft G., Brüel A., Danielsen C., Bor P. \& Oxlund H. (2010) Collagen concentration and biomechanical properties of samples from the lower uterine cervix in relation to age and parity in non-pregnant women. Reproductive Biology and Endocrinology, 8: 82-90. http://dx.doi.org/10.1186/1477-7827-8-82

Robinson R.S., Mann G.E., Lamming G.E. \& Wathes D.C. (2010) Expression of oxytocin, oestrogen and progesterone receptors in uterine biopsy samples throughout the oestrous cycle and early pregnancy in cows. Journal of Reproduction and Fertility, 122: 965-979. http://dx.doi.org/10.1530/rep.0.1220965

Rosselli M., Reinhart K., Imthurn B., Keller P.J. \& Dubey R.K. (2000) Cellular and biochemical mechanisms by which environmental estrogens may influence the reproduction function. Human Reproduction, 6: 332-350. http://dx.doi.org/10.1093/humupd/6.4.332

Saiyn U. (2012) EPR analysis of gamma irradiated single crystal cimetidine. Journal of Molecular Structure, 1031: 132-137. http://dx.doi.org/10.1016/j.molstruc.2012.07.022

Sasso-Cerri E. \& Cerri O.S. (2008) Morphological evidences indicate that the interference of cimetidine on the peritubular components is responsible for detachment and apoptosis of Sertoli cells. Reproductive Biology and Endocrinology, 6:18. http://dx.doi.org/10.1186/14777827-6-18

Silva R.D., Glazebrook M.A., Campos V.N. \& Vascocelos A.C. (2011) Achilles tendinosis - a morphometricalstydy in a rat model. International Journal of Clinical and Experimental Pathology, 4: 683-691. 
Sinha R.B., Banerjee P. \& Ganguly A.K. (2006) Serum concentration of testosterone, epididymal mast cell population and histamine content in relation to sperm count and their motility in albino rats following $\mathrm{H}_{2}$ receptor blocker treatment. Nepal Medical College Journal, 8: 36-39.

Surazynski A., Miltyk W., Wolczynski S. \& Palka J. (2013) The effect of prolactin and estrogen cross-talk on prolidase-dependent signaling in MCF-7 cells. Neoplasma, 60: 355-363. http://dx.doi.org/10.4149/neo_2013_047

Takeshi S., Kai H. \& Suita S. (2002) Effects of the prenatal administration of cimetidine on testicular descent and genital differentiation in rats. Surgery 131: 301-305. http://dx.doi.org/10.1067/msy.2002.119961

Taketani T., Tamura H., Takasaki A., Lee L., Kizuka F. \& Tamura I. (2011) Protective role of melatonin in progesterone production by human luteal cells. Journal Pineal Research, 51(2): 207-213. http://dx.doi.org/10.1111/j.1600-079X.2011.00878.x

Teixeira A.A.C., Simoes M.J., Evencio-Neto J. \& Wanderley-Teixeira V. (2002) Morphologic aspects of endometrium in the estrus phase, of pinealectomized rats. Revista Chilena de Antomia, 20(2): 145-159. http://dx.doi.org/10.4067/S0716-98682002000200005

Teixeira A.A.C., Simões M.J., Wanderley-Teixeira V. \& Soares J.M.Jr. (2004) Evaluation of the implantation in pinealectomized and/or submitted to the constant illumination rats. International Journal of Morphology, 22(3): 189-194. http://dx.doi.org/10.4067/S0717-95022004000300003

Uygur R., Aktas C., Caglar V., Uigur E., Erdogan H. \& Ozen A.O. (2013) Protective effects of melatonin against arsenic-induced apoptosis and oxidative stress in rat testes. Toxicology and Industrial Health, 32(5): 848-859. http://dx.doi.org/10.1177/0748233713512891

Xiang S., Mao L., Yuan L., Duplessis T., Jones F., Hoyle G.W., Frasch T., Dauchy R., Blask D., Chakravarty G. \& Hill S.M. (2012) Impaired mouse mammary gland growth and development is mediated by melatonin and its MT1G protein-coupled receptor via repression of ER $\alpha$, Akt1, and Stat5. Journal of Pineal Research, 53: 307-318. http://dx.doi.org/10.1111/j.1600-079X.2012.01000.x

Zarazaga L., Celi I., Guzmán J.L. \& Malpaux B. (2011) The effect of nutrition on the neural mechanisms potentially involved in melatonin-stimulated LH secretion in female Mediterranean goats. The Journal of Endocrinology, 211: 263-272. http://dx.doi.org/10.1530/JOE-11-0225

Zarazaga L., Celi I., Guzmán J.L. \& Malpaux B. (2012) Reproductive performance is improved during seasonal anoestrus when female and male Murciano-Granadina goats receive melatonin implants and in Payoya goats when females are thus treated. Reproduction in Domestic Animals, 47(3): 436-442. https://doi.org/10.1111/j.1439-0531.2011.01899.x

Zhong L., Xiang X., Lu W., Zhau P. \& Wang (2013) Interference of xenoestrogen o,p'-DDT on the action of endogenous estrogens at environmentally realistic concentrations. Bulletin of Environmental Contamination and Toxicology, 90: 591-595. https://doi.org/10.1007/s00128-013-0976-9

Zuloaga G.Z., Zuloaga K.L., Hinds L.R., Carbone D.L. \& Handa R.J. (2013) Estrogen receptor $\beta$ expression in the mouse forebrain: Age and sex differences. Journal of Comparative Neurology, 522: 358-371. https://doi.org/10.1002/cne.23400 